\title{
CHARACTERIZATION AND HYPOGLYCEMIC STUDY OF ISOLATED NATURAL POLYMER FROM THE STEM OF MANILKARA HEXANDRA (ROXB.) DUBARD
}

\author{
IRUDAYA MONISHA S. ${ }^{*}$, ROSALINE VIMALA J. \\ PG and Research Department of Chemistry, Holy Cross College (Autonomous), Trichy, Tamil Nadu, India \\ Email: irudaya.monisha@gmail.com \\ Received: 09 Mar 2019, Revised and Accepted: 10 May 2019
}

\begin{abstract}
Objective: In the present study, the isolated natural polymer from the stem of Manilkara hexandra and their physiochemical parameters were investigated. It is further involved in hypoglycemic studies.

Methods: The gum exudates were screened for phytochemicals, physicochemically analyzed for solubility, pH, total ash, moisture content, acid insoluble ash, water soluble ash, sulfated ash, flow property, and it is characterized by Fourier Transform Infrared analysis (FT-IR), Scanning Electron Microscope (SEM), X-ray diffraction analysis (XRD), Nuclear Magnetic Resonance (NMR) studies ( ${ }^{13}$ Carbon and ${ }^{1}$ Proton) and it was examined in vitro studies by hypoglycaemic activity.

Results: The isolated gum extracted from the stem of Manilkara hexandra (Roxb.) Dubard ash values were found to be low. The gum is found to be hygroscopic in nature due to its high moisture content $(0.9131 \pm 0.03)$. Fourier Transform Infrared (FT-IR) spectra show relevant functional groups for gum, which is further confirmed by resonance spectral studies. The X-ray diffraction (XRD) pattern shows that the gum is amorphous as well as crystalline in nature. Scanning Electron Microscope (SEM) image confirms that the gum particles have irregular size and shape. Sugar composition analysis by Thin Layer Chromatography indicated the presence of rhamnose, arabinose. The in vitro study of hypoglycemic activity shows the best report compared with the standard. The experimental evidence offers scope to use this natural polymer in the food and pharmaceutical industry.
\end{abstract}

Conclusion: The isolated natural polymer shows good result in hypoglycemic studies compared with standard.

Keywords: Manilkara hexandra, Isolated polymer, Characterization, Hypoglycemic activity

(C) 2019 The Authors. Published by Innovare Academic Sciences Pvt Ltd. This is an open-access article under the CC BY license (http://creativecommons.org/licenses/by/4.0/) DOI: http://dx.doi.org/10.22159/ijap.2019v11i4.32988

\section{INTRODUCTION}

The position of the earth and the environment conditions makes India the best source of natural products among Asian countries [1] Natural products are a precious gift of the plants and an assorted lot of pharmaceutical applications such as adhesives, stabilizers, emulsifiers, diluents, binding agents [2], suppository and thickeners [3]. Apart from these applications, the gums and resins produced naturally still add values such as beautifiers, papermaking, and colorants to materials. Such gum-yielding trees occupy a prime place in Non-Wood Forest Produce. Most forest dwellers a viable source of income is from such resin and gum-producing trees.

From very early times natural gums and resins are being used in food, medicine, industries and also in their manufacturing produces. The present-day usage of gums and resins are innumerable. These natural polymers formed by throwing with $[4,5]$ or without [6] have different properties which depend on their environment $[7,8]$ and also on their physicochemical characteristics [9]. The gums are hydrophilic or hydrocolloids in nature, which means that they are, water-soluble [10]. A number of gums have been studied to validate their pharmacological usage.

The present study deals with the extraction and characterization of gum from the stem of Manilkara hexandra (Roxb.) Dubard (Sapotaceae). It is a huge evergreen tree and broadly present in many regions of India and tropical nations. The stem bark is pleasant, febrifuge, tonic, astringent and medicinal use for helminthiasis, jaundice etc [11]. It is utilized generally to the extensive variety of gastrointestinal manifestations [12]. The seed also contains a medicinal property for piles, ulcers etc [13]. The isolated biopolymer was subjected to micrometric analysis, flow property calculations, characterized by various spectral techniques and evaluated for its hypoglycemic activity.

\section{MATERIALS AND METHODS}

\section{Chemicals and reagents}

Double distilled water, acetone and other chemicals were purchased from Sigma Aldrich (AR grade). HPLC grade solvents such as, were used in Thin-layer Chromatographyic analysis (Merck). Hydrochloric acid, Sulphuric acid and Nitric acid are used in physicochemical parameters.

\section{Collection of plant}

Manilkara hexandra (Roxb.) Dubard (Synonym: Mimusops hexandra Roxb.) were collected from Jayakondam at Ariyalur District, Tamil Nadu India and authenticated by Rapinet Herbarium, St. Joseph's College (Autonomous), Trichy. The sample Voucher number is 00I1. Stems were washed with running water, shade dried, and ground by pestle mortar.

\section{Extraction and isolation of gum}

The stem of Manilkara hexandra $(1 \mathrm{~kg})$ was defatted with petroleum ether and the dried marc was extracted with methanol During the process, all the saponins were removed [12]. The collected marc was treated with double-distilled water and heated at $60^{\circ} \mathrm{C}$. This filtrate was separated by using muslin cloth ( 8 fold). The settled precipitate was kept below $6^{\circ} \mathrm{C}$ by using airtight containers in the refrigerator. This aqueous volume was reduced $(1 / 3)$ by applying heat and added acetone to form a gummy precipitate which is settling down in a beaker. After this, a portion was washed with acetone ( 3 times) and it was separated by using the muslin cloth The gum was dried till it reaches to constant weight at $35-45^{\circ} \mathrm{C}$ in a hot air oven. The dried natural gum was crushed into powder using pestle mortar. Then the isolated polymer powder of Manilkara hexandra gum (MHG) yield percentage was calculated.

\section{Phytochemical screening of isolated polymer}

The natural polymer was screened using a standard harborne procedure to study the phytochemical properties for the presence of alkaloids, flavonoids, proteins, amino acids, saponin, tannins, carbohydrates, fixed oils and fats, and gums [14]. Hydrolysis test was examined [15].

Physicochemical characterization of natural polymer

The physicochemical was examined using standard procedure [16-18]. 


\section{Study of flow property parameters}

\section{Bulk density}

About $10 \mathrm{~g}$ of the Manilkara hexandra gum was exactly weighed and placed in $100 \mathrm{ml}$ measuring cylinder without disturbing. The bulk volume was measured.

$$
\text { Bulk density }(\rho \mathrm{b})=\frac{\text { weight of the sample }}{\text { Bulk volume }}
$$

\section{Tapped density}

It was obtained by using mechanically tapping a cylinder. The tapped volume was calculated from the tap density tester (Electro lab, Nobel ETD 1020).

$$
\text { Tapped density }(\rho t)=\frac{\text { weightofthe sample }}{\text { Trapped volume }}
$$

\section{Compressibility index}

The Carr' index was calculated from the density of the natural polymer by applying the following formula,

$$
\text { Compressibility }(\mathrm{C} \%)=\frac{\text { Tapped density }- \text { Bulk density }}{\text { Tapped density }} \times 100
$$

\section{Hausner ratio}

The flowability of Manilkara hexandra gum (MHG) was calculated by using the Hausner ratio $(\mathrm{H})$. This value was obtained from the following formula,

$$
\text { Hausner ratio }(\mathrm{H})=\frac{\text { Tapped density }}{\text { Bulk density }}
$$

\section{Angle of repose}

The stem of Manilkara hexandra gum (MHG) powder 10g was introduced into a funnel placed on a horizontal paper surface. Height $(\mathrm{H})$ and radius $(\mathrm{R})$ was measured. The angle of repose $(\theta)$ was calculated.

$$
\operatorname{Tan} \theta=\mathrm{H} / \mathrm{R}
$$

\section{Viscosity}

The viscosity of polysaccharide was determined by Oswald's

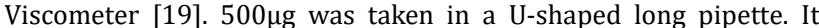
consists of two bulbs with a mark in a glass tube. The flow time of the upper and lower mark volume of the bulb was measured between two liquids and calculated by the formula.

$$
\frac{\eta 1}{\eta 2}=\frac{\mathrm{d} 1 \mathrm{t} 1}{\mathrm{~d} 2 \mathrm{t} 2}
$$

Where,

$\eta_{1}$ and $\eta_{2}=$ Coefficient of viscosity

$\mathrm{d}_{1}$ and $\mathrm{d}_{2}=$ Density

$\mathrm{t}_{1}$ and $\mathrm{t}_{2}=$ Time

\section{Fourier transform infrared analysis (FT-IR)}

The Fourier Transform Infrared analysis (FTIR) spectrum of the gum was studied in the scanning range of 450 to $4500 \mathrm{~cm}^{-1}$ with 1 $\mathrm{cm}^{-1}$ as the resolution.

\section{Scanning electron microscope (SEM)}

The morphological feature (geometry) of the polymer was analyzed at $100 \mu \mathrm{m}$ of voltage $10 \mathrm{kV}$ with different magnification (200 and 213) using the scanning electron microscope (ZEISS).

\section{$\mathrm{X}$-ray diffraction analysis (XRD)}

The natural polymer of stem Manilkara hexandra gum (MHG) was recorded by X-ray diffractometer (Goniometer). This analysis examined at measurement temperature $\left(25^{\circ} \mathrm{C}\right)$, voltage $(40 \mathrm{Kv})$, and current $(30 \mathrm{~mA})$, scan step time (10.16 s), anode material $(\mathrm{Cu})$ and specimen length $(10 \mathrm{~mm})$.

\section{Nuclear magnetic resonance (NMR)}

The Nuclear Magnetic Resonance (NMR) spectra of the gum were recorded in NMR (BRUKER $300 \mathrm{MHz}$ ) Ultra shield Magnet with
AVANCE II type console to identify its structural features. The $\mathrm{H}^{1}$ and $\mathrm{C}^{13}$ NMR were measured from 0-8 ppm and 50-110 ppm respectively.

\section{Estimation of sugar composition by thin layer chromatography}

Mucilages and gums present in plant constituents have pharmaceutical and technical applications which have within them carbohydrates, which are difficult to be analyzed since they are polar and similar structural characteristics. Thin layer chromatography (TLC) was performed to determine the carbohydrates that are available in the gum. The sample was dissolved in double distilled water and spotted in precoated thin layer chromatography (TLC). The Butanol: Acetic Acid: Water (BAW) was highly polar than other systems [20]. So the analysis was done using Butanol: Acetic Acid: Water $(4: 1: 5)$ solvent system on the aluminium plate $(6.5 \times 3.5 \mathrm{~cm})$ with glucose, fructose, sucrose as standard references [21].

In vitro of hypoglycemic activity (Non-insulin dependent diabetes mellitus)

Using phosphate buffer of $\mathrm{pH}=6.9$ varied concentrations such as $100 \mu \mathrm{g} / \mathrm{ml}, 200 \mu \mathrm{g} / \mathrm{ml}, 300 \mu \mathrm{g} / \mathrm{ml}, 400 \mu \mathrm{g} / \mathrm{ml}$, and $500 \mu \mathrm{g} / \mathrm{ml}$ of Manilkara hexandra gum (MHG) extract were prepared. From each of these concentrations $500 \mu \mathrm{l}$ of the extract was withdrawn and to that $20 \mathrm{mmol}$ of the buffer and $0.5 \mathrm{mg} / \mathrm{ml}$ of $\alpha$-amylase were added and incubated at $25{ }^{\circ} \mathrm{C}$ for $10 \mathrm{~min}$. The procedure was repeated by adding $0.5 \%$ starch solution $(1000 \mu \mathrm{l})$ in $20 \mathrm{mmol}$ phosphate buffer and incubated for $10 \mathrm{~min}$ at $25^{\circ}$ C. To that $500 \mu \mathrm{l}$ of 3, 5dinitrosalicyclic acid was added in all the five tubes for color development, followed by incubation in a boiling water bath for 5 $\mathrm{min}$. The tubes were cooled to room temperature and their corresponding absorbance was measured at $540 \mathrm{~nm}$. Acarbose was used as the standard with respect to which the inhibitory activity of $\alpha$-amylase and percentage inhibition was calculated as follows [22].

$$
\% \text { of inhibition }=\frac{(\text { Control O. D. }- \text { Test O. D. })}{\text { Control O. D. }} \times 100
$$

The experiment was performed in triplicate and its standard deviation value was recorded as percentage inhibition.

\section{RESULTS AND DISCUSSION}

\section{Yield percentage}

The yield percentage of the isolated natural polymer (fig. 1) is lesser than one $(0.88<1)$.

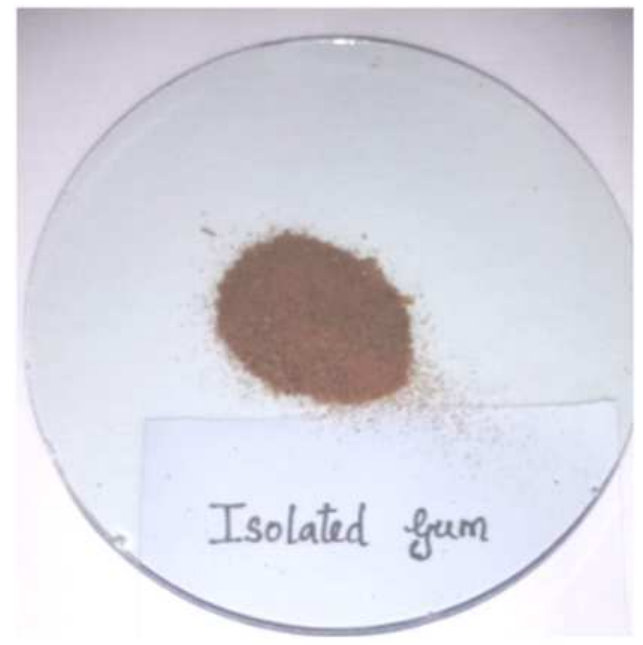

Fig. 1: Isolated natural polymer from the stem of Manilkara hexandra

\section{Phytochemical screening for gum}

The results of the phytochemical screening of gum obtained from the stem of Manilkara hexandra are shown in table 1, fig. $2 \mathrm{a}$ and fig. 
$2 \mathrm{~b}$. The purity of the gum was confirmed from the positive test for carbohydrates and the negative tests for amino acid, alkaloids, protein, oils and fats, flavonoids and tannins which correlates with the report of okra gum [23].

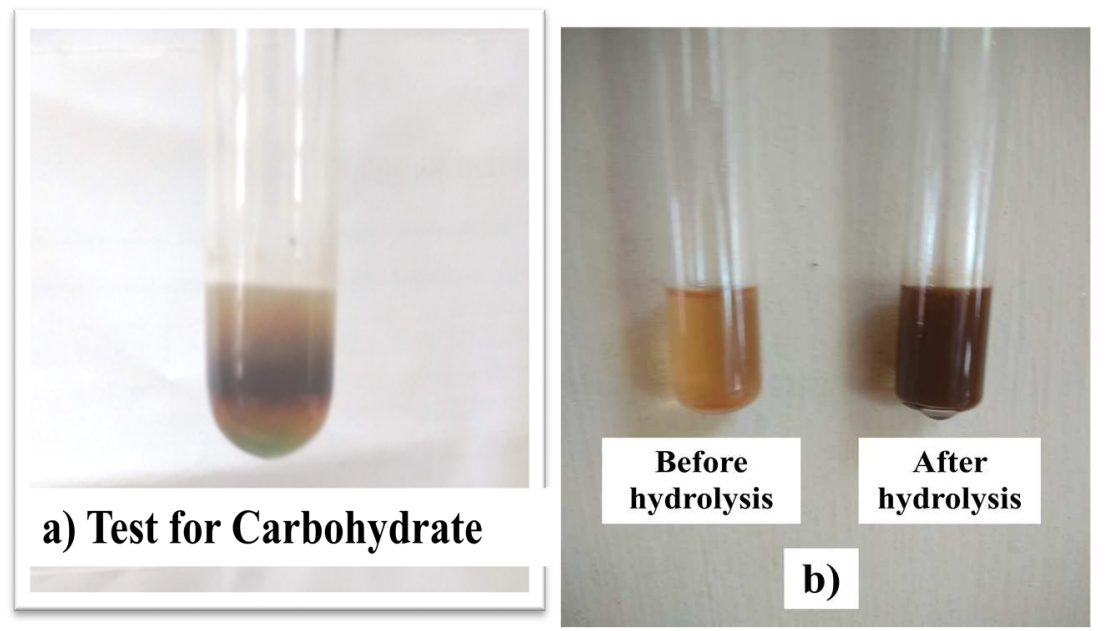

Fig. 2. a.) Molisch test for the stem of Manilkara hexandra gum (MHG), b.) Hydrolysis test

Table 1: Qualitative report for stem of Manilkara hexandra gum (MHG)

\begin{tabular}{lll}
\hline S. No. & Phytocompounds & Observations \\
\hline 1. & Alkaloids & Absent \\
2. & Amino acid & Absent \\
3. & Protein & Absent \\
4. & Flavonoids & Absent \\
5. & Tannins & Absent \\
6. & Oils and Fats & Absent \\
7. & Gum & Present \\
8. & Sugar & Present \\
\hline
\end{tabular}

\section{Physicochemical properties}

This gum separated from the stem of Manilkara hexandra was subject to various physicochemical properties such as solubility shown in table 2 . $\mathrm{pH}$, total ash, moisture content, acid insoluble ash, water-soluble ash and sulphated ash as shown in table 3 . The gum was soluble in water, slightly soluble in petroleum ether, chloroform, Dimethylformamide (DMF), acetone, and practically insoluble in hexane, ethyl acetate, ethanol, methanol. The $\mathrm{pH}$ is $4.98 \pm 0.0112$ which was moderately acidic which nearly match with the fruit mucilage of Chrysophyllum lanceolatum [24]. The low value of total ash $(0.0681 \pm 0.0094)$ sulphated ash $(0.0601 \pm 0.0082)$, water-soluble ash $(0.0341 \pm 0.0059)$, and acid insoluble ash (0.0205 \pm 0.0007$)$ indicates that the sample is more pure. Moisture content depends on the stability of the drug [25]. The high moisture content value $(0.9131 \pm 0.03)$ generally results in particle agglomeration. It is important for aerosol containing powders. Thus, the gum could be used as protective colloids in suspensions, cosmetics, hot beverages and paint making [26].

Table 2: Solubility analysis of the stem of Manilkara hexandra gum (MHG)

\begin{tabular}{llll}
\hline S. No. & Solvents & Solubility & Number of parts \\
\hline 1. & Hexane & Nil & More than 10,000 parts \\
2. & Petroleum ether & Nil & More than 10,000 parts \\
3. & Chloroform & Nil & More than 10,000 parts \\
4. & Ethyl acetate & Nil & More than 10,000 parts \\
5. & Ethanol & Nil & More than 10,000 parts \\
6. & Methanol & Nil & More than 10,000 parts \\
7. & Acetone & Sparingly soluble & $30-100$ parts \\
8. & DMF & Very Soluble & $100-1000$ parts \\
9. & Water & & Less than 1 part \\
\hline
\end{tabular}

Table 3: Study of physicochemical parameters for the stem of Manilkara hexandra gum (MHG)

\begin{tabular}{lll}
\hline S. No. & Physicochemical parameters & Values* \\
\hline 1. & Total ash & $0.068 \pm 0.0094$ \\
2. & Moisture Content & $0.9131 \pm 0.030$ \\
3. & Sulphated ash & $0.1076 \pm 0.0022$ \\
4. & Water soluble ash & $0.0341 \pm 0.0059$ \\
5. & Acid-insoluble ash & $0.0205 \pm 0.0007$ \\
6. & pH & $4.9800 \pm 0.0112$ \\
\hline
\end{tabular}

${ }^{*}$ All the experiments were repeated independently three times and the values were represented as an average means \pm Standard deviation. 


\section{Flow property of the gum}

The flow properties of the gum are shown in table 4 . The results of the flow parameters such as Hausner's ratio and viscosity show that it has low flow property. Bulk density, tapped density and compressibility index values indicate that it is a fine powder. Angle of repose declare the penury glide property which displays stem of Manilkara hexandra gum (MHG) was cohesive [27]. The gum of Manilkara hexandra gum (MHG) is less viscous due to the complex nature of polysaccharide and monosaccharide derivatives found in it [28].

Table 4: Study of flow property parameters for the stem of Manilkara hexandra gum (MHG)

\begin{tabular}{lll}
\hline S. No. & Flow property parameters & Results* $(\overline{\mathbf{x}} \pm \boldsymbol{\sigma})$ \\
\hline 1. & Bulk density $(\mathrm{g} / \mathrm{ml})$ & $0.7591 \pm 0.00001$ \\
2. & Tapped density (g/ml) & $1.1386 \pm 0.00005$ \\
3. & Compressibility index (\%) & $33.56 \pm 0.0426$ \\
4. & Hausner ratio (\%) & $1.5 \pm 0.01$ \\
5. & Angle of repose ( $\left.{ }^{\circ}\right)$ & $49.01 \pm 0.9318^{\circ}$ \\
6. & Viscosity (cP) & $0.93 \pm 0.073$ \\
\hline
\end{tabular}

*All the experiments were repeated independently three times and the values were represented as an average means \pm Standard deviation.

\section{Fourier transforms infrared analysis}

Fig. 3 shows the characteristic absorption band at $3387 \mathrm{~cm}^{-1}$ showing the presence of hydrogen-bonded $\mathrm{O}-\mathrm{H}$ group. The characteristic peak at $3400 \mathrm{~cm}^{-1}-3500 \mathrm{~cm}^{-1}$ for an amino group would have been masked by the broad $\mathrm{O}-\mathrm{H}$ band. The presence of alkane $\mathrm{C}-\mathrm{H}$ stretching, aldehydic $\mathrm{C}-\mathrm{H}$ stretching and sugar, galactose, arabinose, rhamnose is confirmed by the appearance of an absorption peak at $2927 \mathrm{~cm}^{-1}$. The peak at $1622.13 \mathrm{~cm}^{-1}$ is the characteristic band for $\mathrm{C}=\mathrm{C}$ stretch, $\mathrm{N}-\mathrm{H}$ amide bend, $\mathrm{NO}_{2}$ of both aliphatic and aromatic galacto proteins and amino acids of the polymer. The vibrational band at $1323.17 \mathrm{~cm}^{-1}$ and $1419.61 \mathrm{~cm}^{-1}$ are due to $\mathrm{C}=\mathrm{O}$ sym stretch and $\mathrm{O}-\mathrm{H}$ bending of glucoronic acid. Band at $1373.32 \mathrm{~cm}^{-1}$ are characteristics of $\mathrm{CH}_{3}$ bend in alkane, aromatic $\mathrm{C}=\mathrm{C}$ stretch, ketone $\mathrm{C}-\mathrm{C}$ stretch; amine $\mathrm{C}-\mathrm{N}$ stretch of polysaccharides and galacto proteins. Alkane bending and alcohol stretching due to sugar backbone is confirmed by the appearance of peak at $1244.09 \mathrm{~cm}^{-1}$. The alkene $\mathrm{C}-\mathrm{H}$ bends of polysaccharides are found as $1022.27 \mathrm{~cm}^{-1}[29]$.

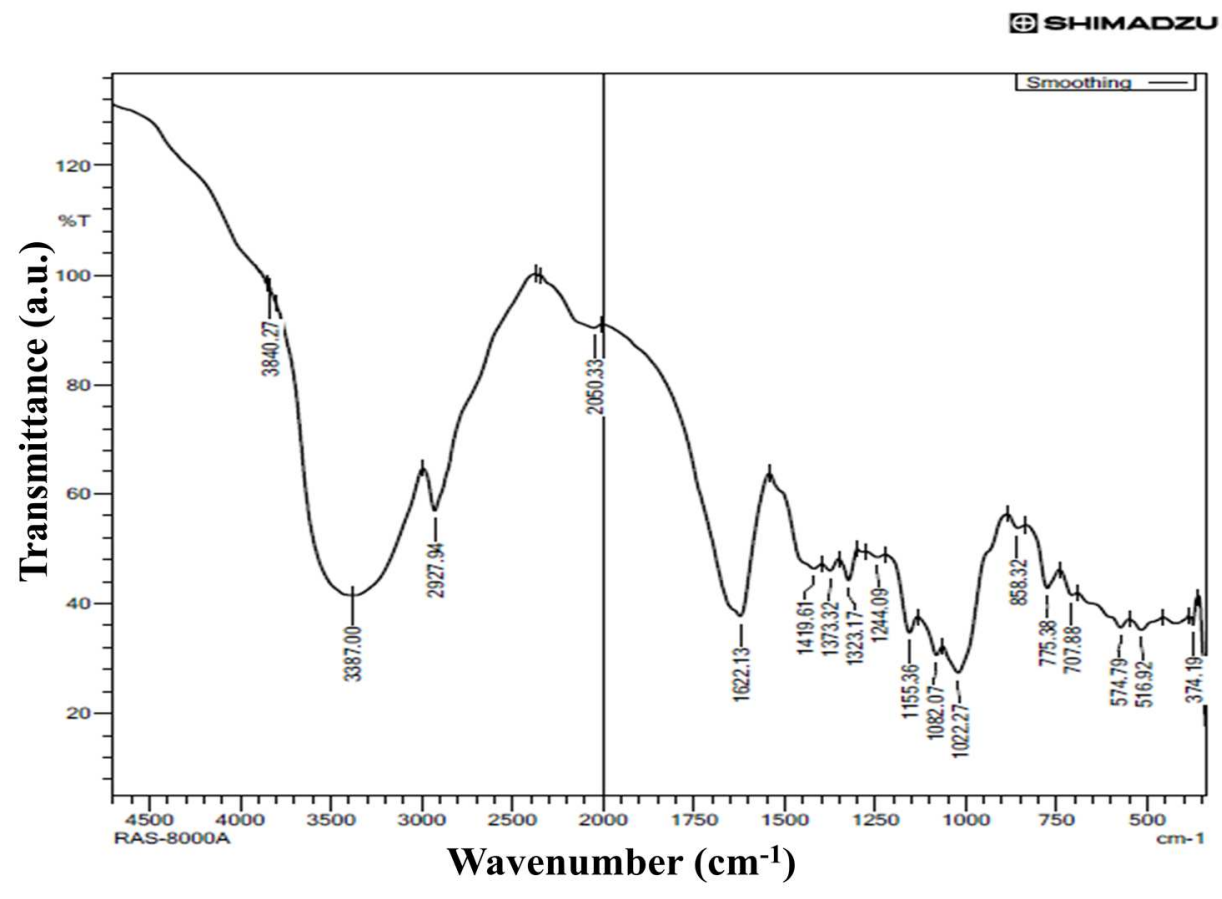

Fig. 3: Fourier transforms infrared spectrum for the stem of Manilkara hexandra gum (MHG)

\section{Scanning electron microscope (SEM)}

The Scanning Electron Microscope (SEM) image of the gum obtained is represented in fig. 4 . The microphotographs of the gum shows that the particles are found as aggregates of irregular dimensions, shape devoid of crystallinity, they are fibrous in nature [21]. The Manilkara hexandra gum (MHG) non-uniform shape, and it retards from the dosage form due to pore size [30, 31].

\section{X-ray diffraction analysis (XRD)}

Physicochemical property of rubbery material depends on the extent of crystallinity of the additives used in polymers. The ease of incorporation and uniformity of dispersion is influenced by the crystalline nature of the polymer matrix, thereby significantly have some role on the physicochemical properties. In view of this X-ray diffraction (XRD) study done for the gummy material is shown in fig. 5. A peak of low intensity at the diffraction angle 2 回 $=24.6^{\circ}$ at the interplanar line spacing of $3.6 \AA$ shows that the gum has a very low degree of crystallinity. Thus, this study supports that it is amorphous as well as crystalline in nature [32]. The obtained $2 \theta\left(23^{\circ}-25^{\circ}\right)$ angle is similar to that of Ocimum basilicum L. seed mucilage [33].

\section{Nuclear magnetic resonance}

The Proton and Carbon Nuclear Magnetic Resonance (NMR) spectrum correlate with the specifications for gum [29]. Using Nuclear Magnetic Resonance (NMR) the structure and property of material (polymer) can be studied. It helps to identify the material, the different functional 
group, detect minor compounds and impurity [34]. The signals between 3 and 6 ppm correspond to polysaccharides. Chemical shift at $1.2 \mathrm{ppm}$ is due to the methyl group of rhamnose. An intense peak at $2.1 \mathrm{ppm}$ shows the presence of an acetyl group. Signals between 3.1 to $4 \mathrm{ppm}$ are due to the methoxy group. The presence of non-anomeric protons are seen by the arisement of peaks between 3.63 ppm-4.70 ppm in ${ }^{1} \mathrm{H}$ Nuclear Magnetic Resonance (NMR) and between 60-85 ppm in ${ }^{13} \mathrm{C}$ spectra. An intense peak at $4.80 \mathrm{ppm}$ is due to water molecules shown in fig. 6a and fig. 6b. Typical ${ }^{1} \mathrm{H}$ and ${ }^{13} \mathrm{C}$ Nuclear Magnetic Resonance (NMR) spectra of the gums are seen by the appearance of peaks in the anomeric region between 4.7-5.9 ppm and 90-110 ppm respectively [35].
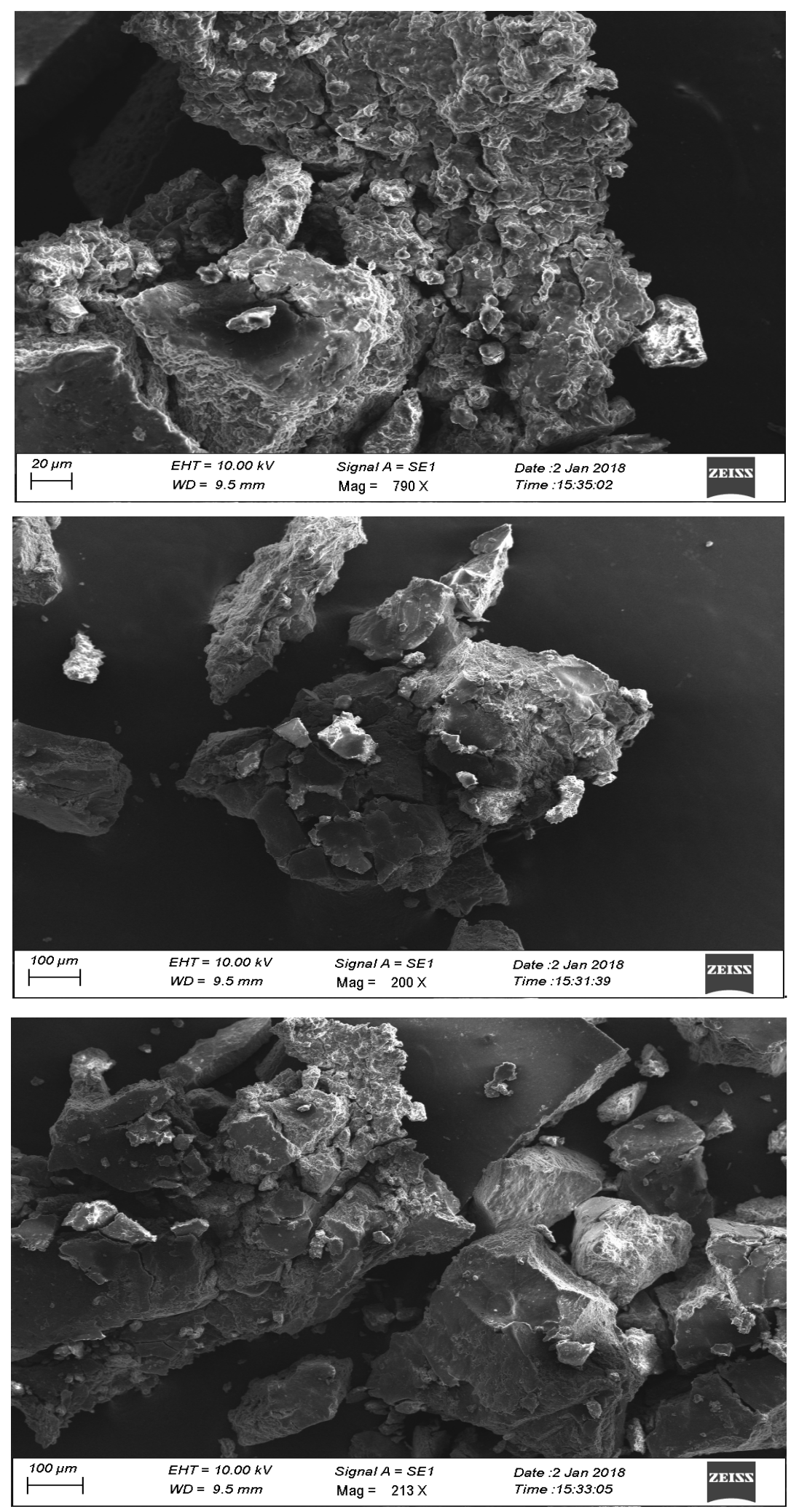

Fig. 4: Scanning electron microscope for the stem of Manilkara hexandra gum (MHG) with various magnifications 


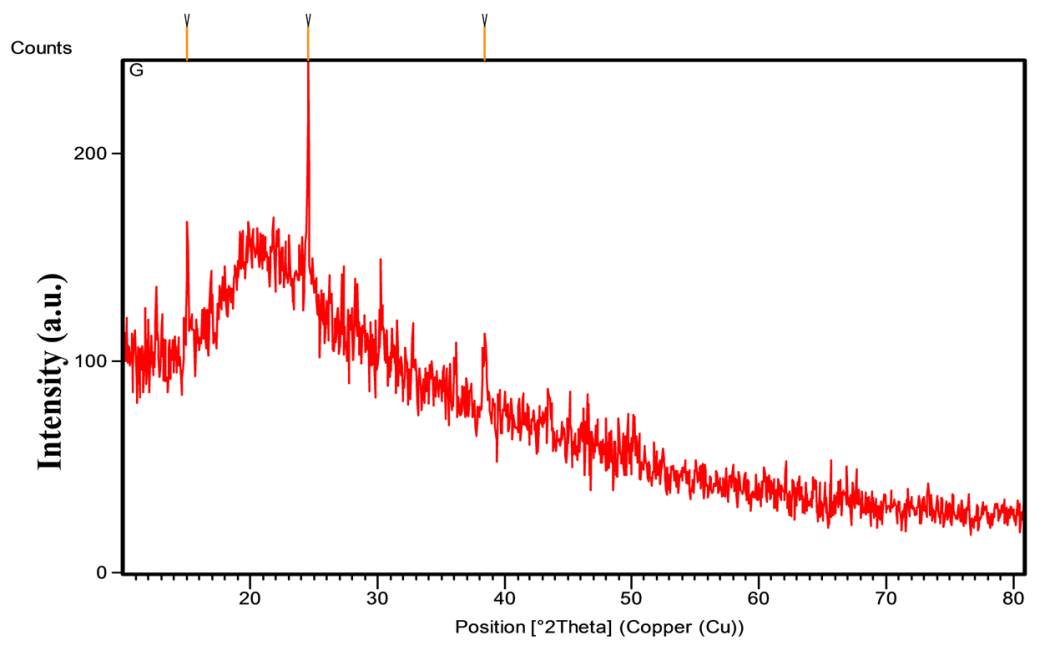

2 Theta $\left({ }^{\circ}\right)$

Fig. 5: X-ray diffraction analysis of the stem of Manilkara hexandra gum (MHG)

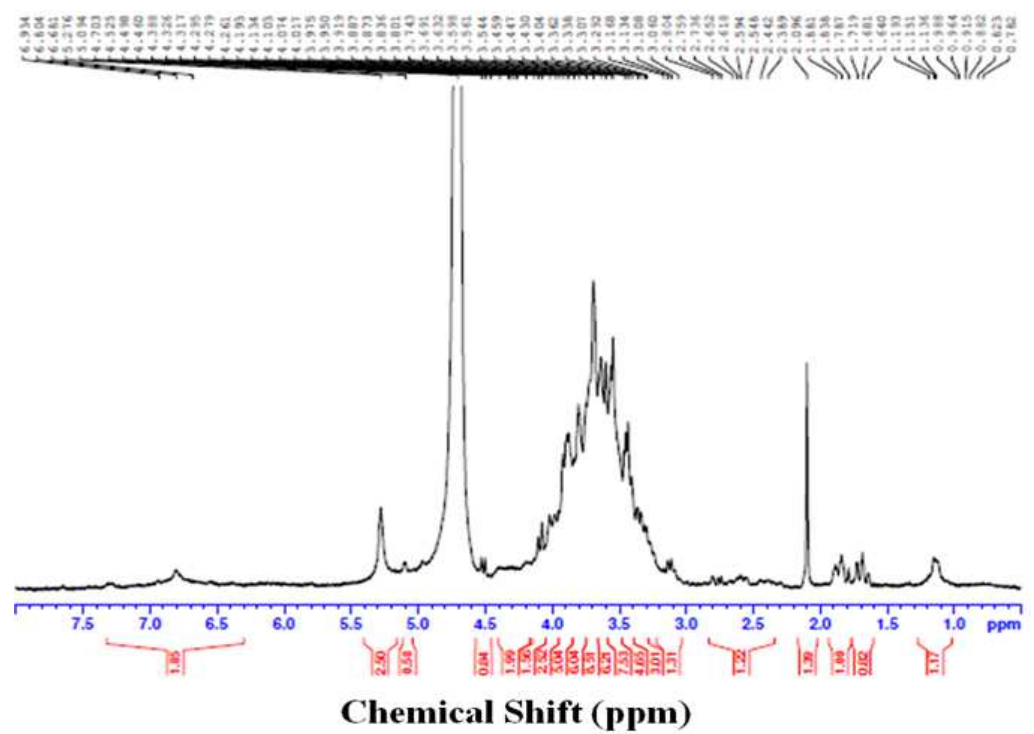

Fig. 6a: ${ }^{1} \mathrm{H}$ nuclear magnetic resonance report for the stem of Manilkara hexandra gum

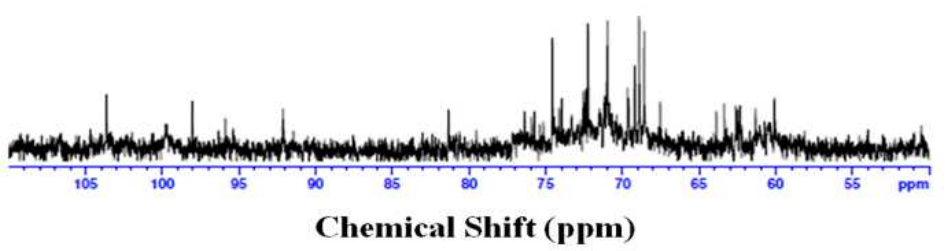

Fig. $6 \mathrm{~b}:{ }^{13} \mathrm{C}$ nuclear magnetic resonance for the stem of Manilkara hexandra gum 


\section{Sugar analysis by the thin layer chromatography}

In drug industry plant material consisting of carbohydrate play a crucial role. Sugar analysis is very tough to identify, due to the presence of high polar compounds. Thin layer chromatography was done to identify the presence of sugar in the stem of Manilkara hexandra gum (MHG). Mucilage is a long chain polysaccharide substance extracted as a viscous or gelatinous dispersion from plant parts (roots, seeds,leaves, fruits etc.) and containing monosaccharides such as L-arabinose, D-galactose, Lrhamnose, D-xylose, and galacturonic acid in various proportions [26]. The $\mathrm{R}_{\mathrm{f}}$ value of Manilkara hexandra gum MHG was similar to the standards of fructose, maltose, and glucose as shown in the table 5 .

Table 5: Comparison of Rf values between standards and the stem of Manilkara hexandra gum

\begin{tabular}{llll}
\hline S. No. & Standards & Rf value & Manilkara hexandra gum (MHG) \\
\hline 1. & Glucose & 0.97 & 0.97 \\
2. & Fructose & 0.32 & 0.34 \\
3. & Maltose & 0.93 & 0.90 \\
\hline
\end{tabular}

\section{Hypoglycemic activity (in vitro)}

Literature review shows that very few research has been carried out on hypoglycemic activity using plant components [36, 37]. Diabetes Mellitus is classified into two ways (i) Type-I (Insulin dependent) (ii) Type-II (NIDDM-Non Insulin Dependent Diabetes Mellitus). In various approaches contains in the pharmacology field for diabetes, such as inhibition of gluconeogenesis, insulin stimulation, glucose transporters, and decreasing the adsorbed glucose from the intestine [38]. Type-II diabetes control the hyperglycemia through hypoglycemic treatment. In this work successfully discussed by the literature data for hypoglycemic activity. Manilkara hexandra gum (MHG) was isolated from aqueous extract since this extract possess active components and it contributes insulin stimulating effect [39] of hypoglycemic activity. The $\alpha$-amylase enzyme used for digestion of carbohydrates or delay the digestion of carbohydrates increasing rate and it also blunts post pradia [40]. This enzyme acts as a major role to break the diasaccharides to monosaccharide [41] and finally all the monosaccharides to form carbohydrates through the absorption of the small intestine [42]. World Health Organization strongly suggested that this plant possess good research on diabetes mellitus [43]. The percentage inhibition of this sample has a significant difference compared with the standard of acarbose. Finally, this reports project the Manilkara hexandra gum may be regulated or control the secretion of insulin level in type-II diabetes mellitus patients. Natural glucose was not alone suitable in diminished blood sugar, regulate metabolism and enhance the insulin activity, but still maintaining the insulin level [44]. The inhibition level was shown in table 6. This reveals that the isolated gum possesses good hypoglycemic activity. The plant efficacy was supported to scientific research and medical evaluation [45].

Table 6: In vitro $\alpha$-amylase inhibition of Manilkara hexandra gum

\begin{tabular}{llll}
\hline S. No. & Concentrations & Manilkara hexandra gum (MHG) & Standard acarbose \\
\cline { 3 - 4 } & & \% of inhibition & \\
\hline 1. & $100 \mu \mathrm{g} / \mathrm{ml}$ & $19.70 \pm 1.38$ & $22.45 \pm 1.57$ \\
2. & $200 \mu \mathrm{g} / \mathrm{ml}$ & $29.57 \pm 2.07$ & $36.61 \pm 2.56$ \\
3. & $300 \mu \mathrm{g} / \mathrm{ml}$ & $58.42 \pm 2.69$ & $55.74 \pm 3.90$ \\
4. & $400 \mu \mathrm{g} / \mathrm{ml}$ & $76.16 \pm 3.93$ & $70.31 \pm 4.92$ \\
5. & $500 \mu \mathrm{g} / \mathrm{ml}$ & 336.84 & $84.84 \pm 5.94$ \\
6. & $\mathrm{IC} 50(\mu \mathrm{g} / \mathrm{ml})$ & 274.79 \\
\hline
\end{tabular}

*All the experiments were repeated independently three times and the values were represented as an average means \pm Standard deviation.

\section{CONCLUSION}

Manilkara hexandra gum (MHG) has a various best approach such as Eco-friendly, biodegradable, non-toxic, cheap, no harmful side effects, natural adhesives. The Screening report confirms the presence of carbohydrates and gums. It is soluble in water, slightly acidic, has high moisture content and poor flow property. Ultimately, it is a fluid cohesive powder. Scanning Electron Microscope (SEM) and X-ray diffraction (XRD) prove that it is crystalline and amorphous in nature. Fourier Transform Infrared analysis (FT-IR), Nuclear Magnetic Resonance $\left({ }^{1} \mathrm{H}\right.$ and $\left.{ }^{13} \mathrm{C}\right)$ and the thin layer chromatography confirm the presence of the sugar moiety. Today community faces many obstacles based on the diabetic disorder. From the hypoglycemic activity analyzed it shows that this polymer may be dealt with the crucial issue of obesity owing to the unbalanced secretion of insulin. This research concludes that the isolated gum could be implemented in the food additive, pharmaceutical and medical model system.

\section{ACKNOWLEDGMENT}

I extend my sincere gratitude to Dr. J. Rosaline Vimala, Department of Chemistry, Holy Cross College (Autonomous), Trichy.

\section{AUTHORS CONTRIBUTIONS}

All the author have contributed equally

\section{CONFLICT OF INTERESTS}

Declared none

\section{REFERENCES}

1. Choudhary PD, Pawar HA. Recently investigated natural gums and mucilages as pharmaceutical excipients: an overview. J Pharm 2014. http://dx.doi.org/10.1155/2014/204849

2. Guo JH, Skinner GW, Harcum WW, Barnum PE. Pharmaceutical applications of naturally occurring water-soluble polymers. Pharm Sci Technol Today 1998;1:254-61.

3. Reiger MM, Banker GS. Pharmaceutical dosage forms-disperse systems. Vol. 2. $2^{\text {nd }}$ ed. New York, USA: Marcel Dekker; 1988.

4. Malviya R. Extraction and characterization of selected gum as a pharmaceutical excipients. Polim Med 2011;41:39-44.

5. Sujitha B, Krishnamoorthy B, Muthukumaran M. A role of natural polymers used in the formulation of the pharmaceutical dosage form. Int J Pharm Technol 2012;4:2347-62.

6. Pawan P, Mayur P, Ashwin S. Role of natural polymer in sustained release drug delivery system. Int Res J Pharm 2001;2:6-11.

7. Chikamai B. Production, markets and quality control of gum Arabic in Africa: findings and recommendations from an FAO project. Paper presented at the Regional Conference for Africa on Conservation, Management and Utilisation of Plant Gums, Resins and Essential Oils Nairobi (Kenya); 1998.

8. Yebeyen D, Lemenih M, Feleke S. Characteristics and quality of gum Arabic from naturally grown Acacia Senegal (Linne) willd. Trees in the central rift calley of Ethiopia. Food Hydrocoll 2009;23:175-80. 
9. Taha KK, Elmahi RH, Hassan EA, Ahmed SE, Shyoub MH. Analytical study on three types of gum from sudan. J For Prod Ind 2012;1:11-6.

10. Phillips GO, Williams PA. Handbook of hydrocolloids. $2^{\text {nd }}$ ed. Cambridge: Woodhead Publishers; 2000.

11. Gopalakrishnan B, Shimpi SN, Ringmichon CL. Stem bark of Manilkara hexandra (Roxb.) dubard-pharmacognosy. World J Pharm Pharm Sci 2014;3:2503-11.

12. Warrier PK, Nambiar VPK, Ramankutty C. Indian Med Plants. A Compendium of 500 species Vaidyaratnam P. S. Varier's Arya Vaidyasala, Kottakal. Vol. 3. Orient Longman Chennai, India; 1995. p. 393.

13. Gopalkrishnan B. Pharmacognostic evaluation of Manilkara hexandra (Roxb.) dubard seeds. Int J Pharmacogn Phytochem Res 2017;9:1359-62.

14. Harborne JB. A guide to modern techniques of plant analysis. USA: Kluwer Academic Publisher; 1998.

15. Dan Howard. How to hydrolyze starch with heat and hydrochloric acid; 2018. Available from: https:// sciencing.com/hydrolyze-starch-heat-hydrochloric-acid7789965.html. [Last accessed on 05 Feb 2019].

16. Anonymous. The Ayurvedic Pharmacopoeia of India, Government of India, Ministry of Health and Family Welfare. Civil Lines, New Delhi: Controller of Publications; 2001.

17. Anonymous, The Wealth of India, Raw Materials, Publication and Information Directorate, CSIR, New Delhi; 1962;6:298-301.

18. Quality Control Methods for herbal Materials. World Health Organisation, Geneva, Switzerland: WHO Press; 2007.

19. Nomura H, Koda S, Hattori F. Viscosity of aqueous solutions of polysaccharides and their carboxylate derivatives. J Appl Polym Sci 1990;41:2959-69.

20. Dafam DG, Nuhu H, Ohemu TL, Olotu PN, Kagaru DC, Abubakar MS. Pharmacognostic studies and chromatographic analysis of the gum of Anacardium occidentale L (Anacardiaceae). J Appl Pharm Sci 2014;4:61-3.

21. Singh S, Bothara SB. Manilkara Zapota (Linn.) seeds: a potential source of natural gum. ISRN Pharmaceutics 2014. http://dx.doi.org/10.1155/2014/647174.

22. Apostolidis E, Kwon YI, Shetty K. Inhibitory potential of herb, fruit, and fungus enriched cheese against key enzymes linked to type 2 diabetes and hypertension. Inn Food Sci Emerg Technol 2007;8:46-54.

23. Shayeri Chatterjee, Rana Mazumder. Novel approach of extraction and characterization of okra gum as a binder for tablet formulation. Asian J Pharm Clin Res 2019;12:189-92.

24. Amal Kumar Boruah, Lila Kanta Nath. Extraction, purification and physicochemical evaluation of mucilage of Chrysophyllum lanceolatum (Blume) dc fruits: an investigation for bioadhesive property. Int J Pharm Pharm Sci 2016;8:282-8.

25. Saba Abdulhadi Jabir, Halah Talal Sulaiman. Preparation and characterization of lafutidine as immediate release oral strip using a different type of water-soluble polymer. Int J Appl Pharm 2018;10:249-60.

26. Jani GK, Shah DP, Prajapati VD, Jain VC. Gums and mucilages: versatile excipients for pharmaceutical formulations. Asian J Pharm Sci 2009;4:309-23.

27. Guerin E, Tchoreloff $\mathrm{P}$, Leclerc $\mathrm{B}$, Tanguy $\mathrm{D}$, Deleuil $\mathrm{M}$ Couarraze G. Rheological characterization of pharmaceutical powder using tap testing, shear cell and mercury porosimeter. Int J Pharm 1999;189:91-103.
28. Sharma DR, Sharma A, Kaundal A, Rai PK. Herbal gums and mucilage as excipients for pharmaceutical products. Res J Pharmacogn Phytochem 2016;8:145-52.

29. Daoub RMA, Elmubarak AH, Misran M, Hassan EA, Osman ME. Characterization and functional properties of some natural Acacia gums. J Saudi Soc Agric Sci 2018;17:241-9.

30. Malviya R, Shukla P, Srivastava P. Preparation, characterization and evaluation of chitosan-gum arabic coacervates as an excipient in fast disintegrating/dissolving drug delivery system. FABAD J Pharm Sci 2009;34:213-23.

31. Kumar P, Kulkarni GJ. Characterization of mucilage from Artocarpus heterophyllus as a pharmaceutical excipient. J Chronother Drug Delivery 2013;4:31-43.

32. Ghosp AK. Characterization and evaluation of a novel renewable plant product (RPP) gum as a flame retardant additive in chloroprene and natural rubber. Int J Plast Technol 2015; 19:19-29.

33. Dhruti Avlani, Vaibhav Agarwal, Vansh Khattry, Gopa Roy Biswas, Sutapa Biswas Majee. Exploring properties of sweet basil seed mucilage in development of pharmaceutical suspensions and surfactant-free stable emulsions. Int J Appl Pharm 2019;11:124-9.

34. Cheng HN, Neiss TG. Solution NMR spectroscopy of food polysaccharides. Polymer Rev 2012;52:81-14.

35. Nep EI, Conway BR. Characterization of grewia gum, a potential pharamaceutical excipient. J Excipients Food Chem 2010;1:30-40.

36. Zinman B, Tildesley H, Chiasson JL, Tsui E, Strack T. Insulin lispro in CSII: results of a double-blind crossover study. Diabetes 1997;46:440-3.

37. Melki V, Renard E, Vague VL, Boivin S, Guerci B, Broutin HH, et al. Improvement of HbA1c and blood glucose stability in IDDM patients treated with lispro insulin analog in external pumps. Diabetes Care 1998;24:977-82.

38. Youn JY, Park HY, Cho KH. Anti-hyperglycemic activity of Commelina communis L.: inhibition of alpha-glucosidase. Diabetes Res Clin Practice 2004;66:149-55.

39. Patel DK, Prasad SK, Kumar R, Hemalatha S. An overview on antidiabetic medicinal plants having insulin mimetic property. Asian Pac J Trop Biomed 2012;2:320-30.

40. Rhabasa Lhoret R, Chiasson JL. Alpha-glucosidase inhibitors. In: Defronzo RA, Ferrannini E, Keen H, Zimmet P. (Eds.) International textbook of diabetes mellitus. John Wiley and Sons., Ltd, UK; 2004. p. 901-14.

41. Kotowaroo MI, Mahomoodally MF, Gurib-Fakim A, Subratty AH. Screening of traditional antidiabetic medicinal plants of Mauritius for possible $\alpha$-amylase inhibitory effects in vitro. Phytother Res 2006;20:228-31.

42. Funke I, Melzig MF. Traditionally used plants in diabetes therapy-phytotherapeutics as inhibitors of $\alpha$-amylase activity. Brazilian J Pharmacogn 2006;16:1-5.

43. Trishna Das, Bhabesh Das, Dipankar Saha, Shanti Bhushan Mishra. Anti-hyperglycemic activity of hydro-alcoholic bark extract of manilkara hexandra (roxb) in streptozotocin-induced diabetic rats. Int J Pharm Pharm Sci 2016;8:185-8.

44. Xiagen Ma, Xiaojing Wang, Shuangli Fan, Jiozhong Chen. Study on extraction process and activity of plant polysaccharides. $2^{\text {nd }}$ International Conference on Materials Science, Resource and Environmental Engineering; 2017.

45. Mani Rupeshkumar, Kunchu Kavitha, Pallab Kanti Haldar. Role of herbal plants in the diabetes mellitus therapy: an overview. Int J Appl Pharm 2014;6:1-3. 